\title{
ANALYSIS OF THE CONTRIBUTION OF RAINWATER RECYCLING (RWR) TO THE CAMPUS AREA \\ Makbulenur BEKAR ${ }^{*}$, Emrah YALÇINALP ${ }^{1}$, Alperen MERAL ${ }^{2}$
}

${ }^{1}$ Karadeniz Technical University, Department of Landscape Architecture, Turkey, mnurbekar@ktu.edu.tr (M.B.), yalcinalp@ktu.edu.tr (E.Y.)

${ }^{2}$ Bingol University, Department of Landscape Architecture, Turkey. alperenmeral@ bingol.edu.tr *Corresponding Author: mnurbekar@ktu.edu.tr

Abstract

The reserves of water, which is one of the most important requirements for human life, gradually decreases under current conditions and rapidly depletes despite being one of the renewable resources. Considering the global water reserves, it became imperative to implement measures to protect the anticipated water reserves. The fact that the amount of quality water per capita decreases every day in the world and the increasing competition in water management could be considered among the indicators of the above-mentioned case. In recent years, as the effects of this adversity became increasingly more evident, several sustainable methods were adopted all over the world such as rain gardens and rain water storage facilities. These sustainable techniques could be observed in many areas, especially in urban centers.

In the present study, the area with the highest water collection was determined at Karadeniz Technical University Kanuni Campus and identified as the study area. Precipitation per square meter and surface runoff volume were identified based on the GIS (Geographic Information System) data, annual water collection volume was calculated, and information on economic and ecological recycling of the water was provided.

In conclusion, the precipitation data for 11 years were compared, and it was calculated that the average annual precipitation was $64.06 \mathrm{~kg} / \mathrm{m}^{2}$ and annual surface runoff water was $552.77 \mathrm{~m}^{3}$. Based on the surface runoff water volume in the months when no irrigation is conducted, a reservoir was designed under the vehicle road and water recycling recommendations were developed.

Keywords: Irrigation, rainwater harvest, surface runoff, ecologic recycling, landscape ecology.

\section{Introduction}


Water, which is one of the most important requirements for human life, has been used for a long time in the fields of agriculture, industry and technology as well as to fulfill the needs of the human body (Maden, 2013; Bayramoglu, Demirel, 2011). Efforts to develop water resources to serve the human needs have started thousands of years ago and continued to improve parallel to technological developments (Bilen, 2015; Dihkan et al., 2017). Although water is a renewable resource, it has been consumed before completing the cycle due to population growth, environmental pollution, irregular water consumption and climate change. Due to the facts that only a small portion of the global fresh water resources could be used, and the distribution of the water resources is not equal to geographical distribution of the population densities, continuous water shortages are experienced especially in certain regions (Sahin, Manioglu 2011; Zeisl, 2018; Bayramoglu, Demirel 2016). As a result of climate change and urbanization of water basins, the water cycle and water ecosystem are significantly affected (Kim et al., 2018). Rainwater plays a key role in this process (Huang, Xu 2016). Due to the seriousness and urgency of pollution, several studies are conducted by various international public and private organizations. Sustainable land use and environmentally sensitive water cycles such as Sustainable Urban Drainage System (SUDS), Water Sensitive Urban Design (WSUD) and Low Impact Development (LID) are actively researched (Kim et al., 2018). Thus, the strategic importance of water is increasing, and water recycling could be achieved using several solutions (de Miguel, 2015; Guneroglu et al., 2015; Guneroglu, 2017; Gulpınar Sekban et al., 2019).

Legislation on preservation and management of water resources is very important in the EU legislation and it includes more than twenty directives in this field. The most important directive is the Water Framework Directive dated October 23, 2000 (no: 2000/60/EC). The EU aimed to manage all European water policies within a single framework, rather than developing different policies for different sectors related to water. The main principle of the Directive defined water as "a non-commercial product and a heritage that should be preserved, protected and properly treated." The Directive stipulates a new and holistic approach based on the abovequoted main principle (Muluk et al., 2013). Today, these approaches include rain gardens and rainwater collection reservoirs. The gardens constructed in hollow areas where the rainwater is collected without and processing and plants could be grown on top are called rain gardens. The plants used in rain gardens, designed to catch the dirty rainwater flow on the impermeable surfaces such as roofs, roads and pavements and transfer the water into the soil, clean the pollutants in the rainwater and feed the groundwater and prevent floods and erosion. 
Furthermore, the plants used in rain gardens provide a new habitat for natural pollinators such as butterflies and bees (Muftuoğlu and Percin, 2015).

The system adopted in rain gardens is a rational, strategic and easy application based on the prevention of rain water surface runoff, leakage to lower strata on precipitation location, and the absorption of the water by the soil like a sponge (Muftuoğlu and Percin, 2015). These gardens are shallow pits where plant groups such as trees and shrubs, and constructed with a layer of mulch, ground cover or coating material. Thus, they allow rainwater to penetrate and replenish the aquifers and to reduce peak flows (Dietz, Clausen, 2005; Ma et al., 2018). Rain gardens, also called bio-prevention applications, are shallow, vegetation-filled depressions designed to receive the rainwater from water-impermeable surfaces (Stander et al., 2010). Rainwater reservoirs are used in several locations such as above and below the ground, and collected water is distributed to necessary facilities. Factors such as the potential highprecipitation area and lack of distribution of the accumulated water due to slope improve the feasibility of a reservoir in that area.

Most studies on rain gardens and rainwater harvest focused on the physical and chemical functions of these designs. These include flow management, removal of pollutants (Davis et al., 2001; Davis et al., 2003; Davis et al., 2006; Hong et al., 2006; Aravena et al., 2009) and various methods based on these functions (Dietz et al., 2006; Flores et al., 2016A; Flores et al., 2016B). In recent years, due to the increasing water recycling requirements, rainwater collection reduced the drinking water consumption considerably. A significant volume of total global water resources is consumed as drinking, agricultural and tap water. This consumption reaches quite a volume at Karadeniz Technical University, which is the primary material in the present study. Because, Karadeniz Technical University employs 2077 academic personnel serving 40,000 students (URL-1). Based on personal, irrigation and other requirements, the consumption figure is quite large. Thus, reducing water consumption in the campus became a requirement.

Rain garden and rainwater harvesting is a common field of study for several professional disciplines, including landscape architecture. The present study aimed to develop a different rainwater recycling approach besides the physical and chemical functions of rainwater recycling that contributes significantly to the city.

The primary aim of the present study was to determine ecological and economic benefits of rainwater harvest at Karadeniz Technical University, located in Trabzon province at the most rainy climate region in Turkey, based on precipitation per square meter and surface runoff GIS 
data for the region and the contribution of the sustainable use of rainwater at KTU Kanuni Campus and resulting water savings.

In order to create a sustainable, future-oriented campus, the introduction of urban ecology studies to the campus is one of the important opportunities provided by the present study. Thus, the sample application study developed in the present study was discussed within the context of method proposal in landscape architecture discipline. Concurrently, it was predicted that the study area would provide an example for future studies due to fact that it included a university campus.

Based on the collected data, a system was proposed for the pilot area identified in the campus (Figures 1-2-4), and the benefits of the system for the campus were determined with a discovery-quantity survey and the ecological significance of the rainwater recycling was emphasized.

The research questions were determined as the benefits of the system for the campus, the depreciation period, the technique that could be utilized in construction and the possible uses of recycled rainwater in the campus if the proposed system is constructed.

\section{MATERIAL AND METHOD}

\section{Study Area}

The study was conducted at Karadeniz Technical University Kanuni Campus, located in the province of Trabzon in the Eastern Black Sea region in Turkey (Figure 1). Trabzon, which has a surface area of $4.664 \mathrm{~km}^{2}$, is located between $38^{\circ} 30^{\prime}-40^{\circ} 30^{\prime}$ east meridians and $40^{\circ} 30^{\prime}-$ $41^{\circ} 30^{\prime}$ north parallels on the northern slopes of the Kalkanlı mountainous mass at the middle of the arc formed by the Eastern Black Sea Mountains (Figure 1) (URL-3). Karadeniz Technical University Kanuni Campus is located between 40,992428 latitude and 39,768364 longitude (URL-1) (Figure 1). Established in May 1955, Karadeniz Technical University includes 12 faculties, 1 higher education school, 6 institutes, 8 vocational schools and 28 applied research centers, 2077 academic personnel (URL-2). Karadeniz Technical University campus covers an area of 1,053,839 $\mathrm{m}^{2}$. The university, which provides education for 61000 students, provides several indoor and outdoor facilities for many activities (Demirtas et al., 2008). 


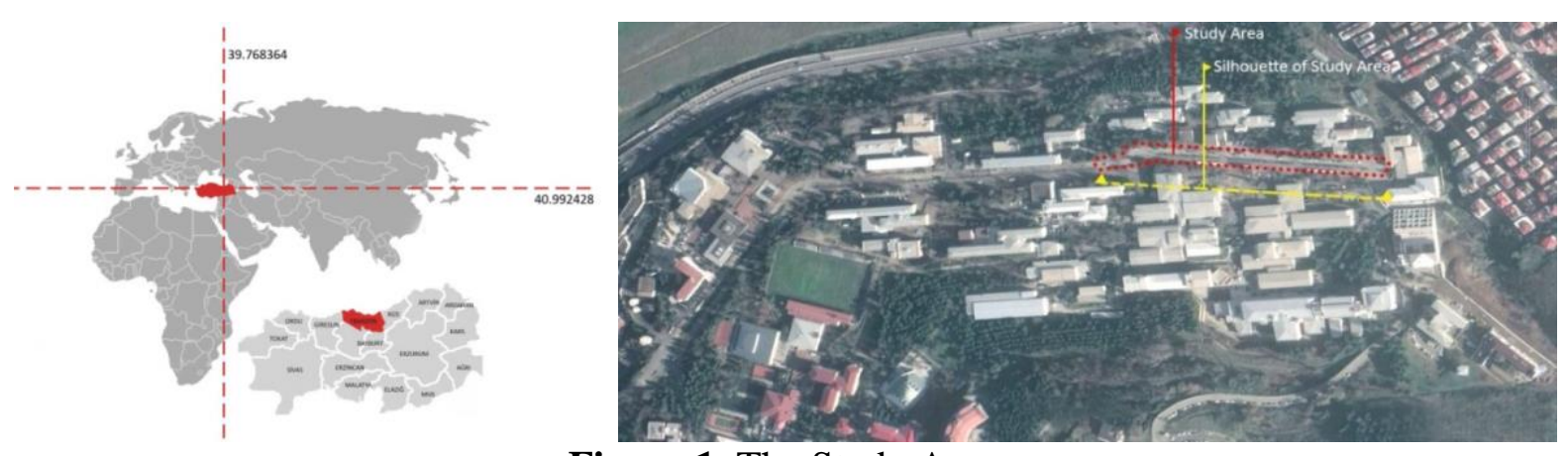

Figure 1. The Study Area

\section{Study Area Climate Data}

The climate is generally temperate under the influence of the sea in Trabzon (Akkas, 1990; Gültekin et al., 2012). Precipitation is mostly in the form of rain in coastal areas and in the form of snow in middle and high regions. Humid land masses in the region cause precipitation and frequent showers in coastal areas (URL-4). In the region with a high annual rainfall precipitation is usually over $1000 \mathrm{~mm}$ with exceptions and increases from east to west. Furthermore, monthly rainfall is over 40-60 mm (Akman, 1990). The annual precipitation in the province and throughout the year and the formation of precipitation due to its coastal nature are due to the relation between the steep slopes of the land on coastal areas, the Black Sea and the temperatures (URL-4). The average annual high temperature is observed in August (23.4), the maximum temperature is observed in July (25.8), the average annual lowest temperature is observed in August (20.4) and the highest average sunshine period is observed in June (7.0) (Table 1).

Table 1. Annual and monthly temperature data for Trabzon (MGM, 2018)

\begin{tabular}{|c|c|c|c|c|c|c|c|c|c|c|c|c|c|}
\hline & $\begin{array}{l}\text { Januar } \\
\mathrm{y}\end{array}$ & $\begin{array}{l}\text { Februar } \\
\mathrm{y}\end{array}$ & $\begin{array}{l}\text { Marc } \\
\mathrm{h}\end{array}$ & $\begin{array}{l}\text { Apri } \\
1\end{array}$ & May & June & July & $\begin{array}{l}\text { Agus } \\
\mathrm{t}\end{array}$ & $\begin{array}{l}\text { Septembe } \\
\mathrm{r}\end{array}$ & $\begin{array}{l}\text { Octobe } \\
\mathrm{r}\end{array}$ & $\begin{array}{l}\text { Novembe } \\
\mathrm{t}\end{array}$ & $\begin{array}{l}\text { Decembe } \\
\mathrm{r}\end{array}$ & $\begin{array}{l}\text { Yearl } \\
\mathrm{y}\end{array}$ \\
\hline & \multicolumn{13}{|c|}{ Measuring Period 1927-2018 } \\
\hline $\mathbf{A}$ & 7,3 & 7,2 & 8,3 & 11,7 & $\begin{array}{l}15, \\
9\end{array}$ & $\begin{array}{l}20, \\
3\end{array}$ & $\begin{array}{l}23, \\
1\end{array}$ & 23,4 & 20,3 & 16,6 & 12,8 & 9,5 & 14,7 \\
\hline B & 10,7 & 10,7 & 11,8 & 15,5 & $\begin{array}{l}19, \\
1\end{array}$ & $\begin{array}{l}23, \\
1 \\
\end{array}$ & $\begin{array}{l}25, \\
8 \\
\end{array}$ & 26,5 & 23,6 & 20,0 & 16,4 & 12,9 & 18,0 \\
\hline C & 4,5 & 4,3 & 5,3 & 8,6 & $\begin{array}{l}12, \\
8\end{array}$ & $\begin{array}{l}16, \\
9\end{array}$ & $\begin{array}{l}19, \\
8\end{array}$ & 20,3 & 17,3 & 13,6 & 9,9 & 6,6 & 11,7 \\
\hline D & 2,7 & 3,2 & 3,4 & 4,2 & 5,5 & 7,0 & 5,9 & 5,6 & 4,9 & 4,5 & 3,6 & 2,7 & 53,2 \\
\hline
\end{tabular}

Data obtained from Trabzon General Directorate of Meteorology (Ortahisar Station) were analyzed and the average annual rainfall for 11 years was calculated in $\mathrm{kg} / \mathrm{m}^{2}$. The average 
precipitation for 11 years was determined as $64.06 \mathrm{~kg} / \mathrm{m}^{2}$ and the surface runoff rate was calculated based on this figure (Figure 2).

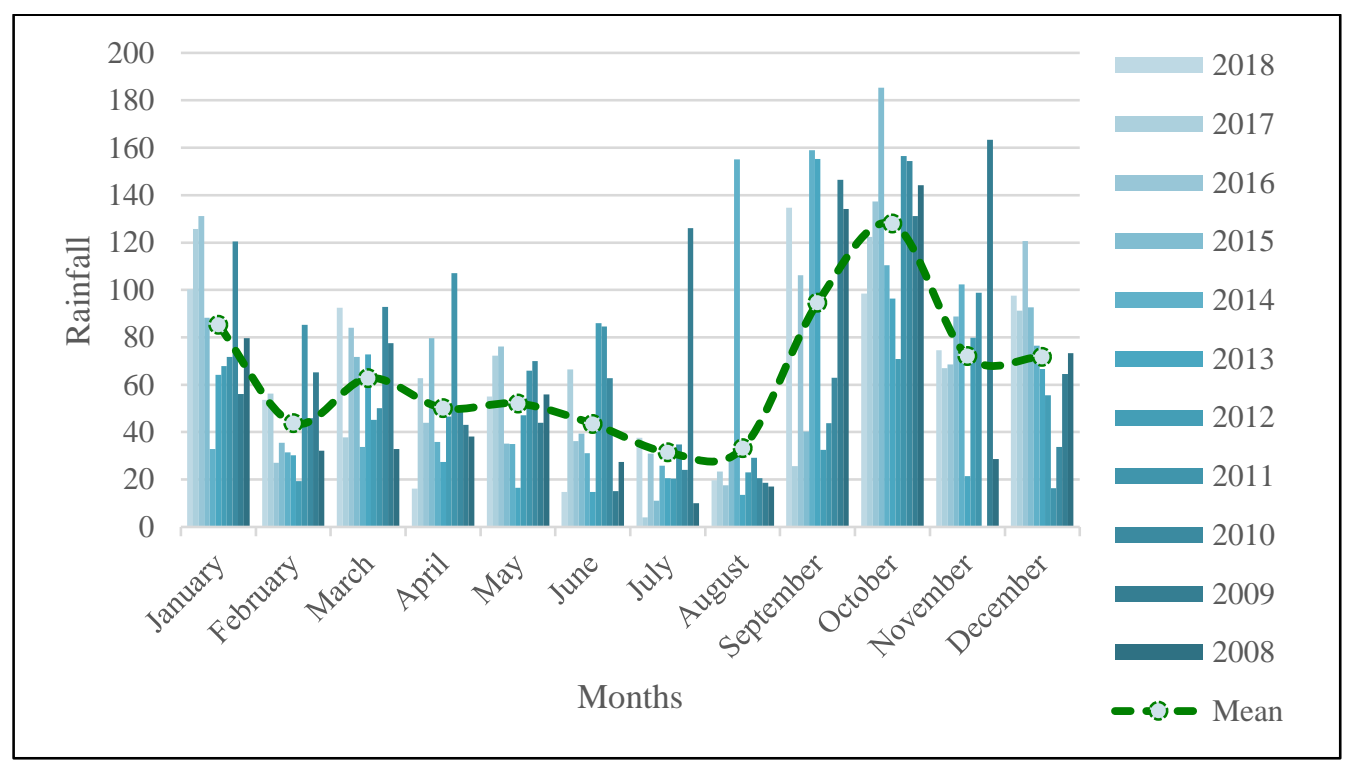

Figure 2.Trabzon Province Ortahisar District 11-year precipitation data $\left(\mathrm{kg} / \mathrm{m}^{2}\right)(\mathrm{MGM}$, 2018)

\section{Method}

Geographic Information System (GIS), one of the methods developed for planning and management phases, was used in the present study. Because, the most frequently used software to conduct sound and error-free planning and management phases is the Geographic Information System (Sogut, 2005; Gulpınar Sekban, 2018). Thus, ArcGis 10.6 software was used to determine the potential area for rainwater recycling and the requirement of the present study in the sample area. In the present study, the digital terrain model (Figure 7A), digital altitude map (Figure 7B), slope map (Figure 8A), and exposure map (Figure 8B) were generated with ArcGIS 10.6 software along with the existing maps and DAM data, and the collected data were analyzed. The GIS data and on-site observations were used to determine the most suitable location for the future rainwater collection center. Based on these data, a system was proposed in the pilot area (Figures 3,4). The system included an isolated an underground concrete reservoir that collects the rainwater (Figure 5). The diagram that includes all methodological stages is presented in Figure 2. 


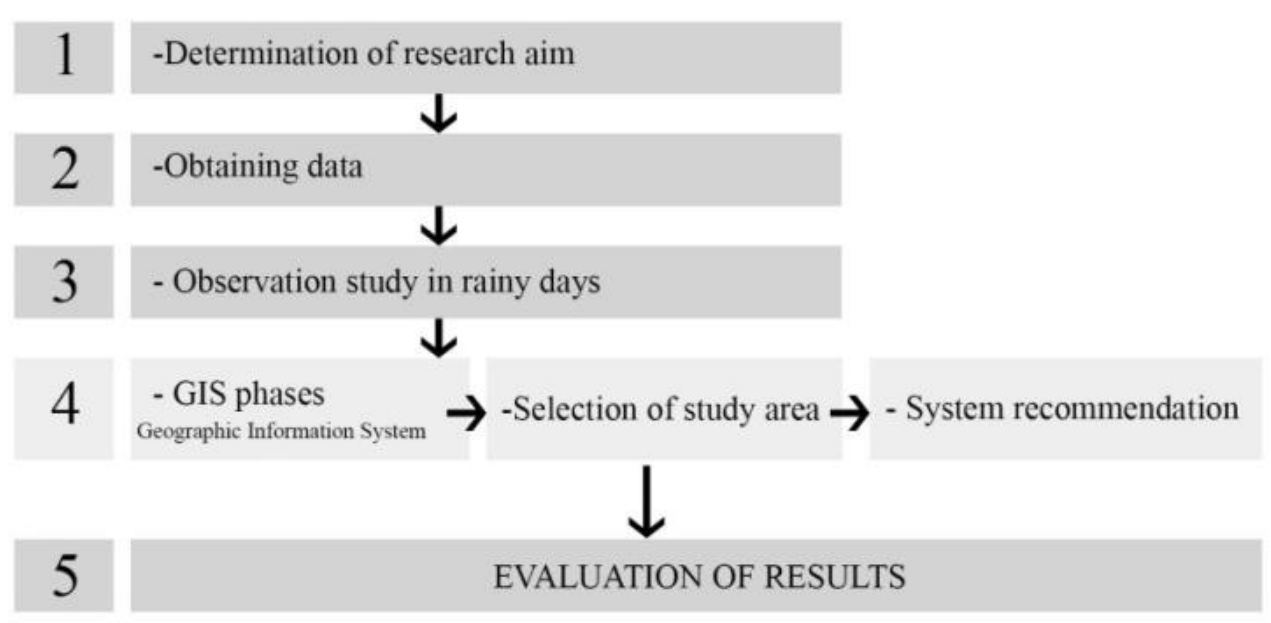

Figure 2. The study method diagram

\section{Selection of the potential rainwater collection reservoir location}

Transportation is distributed over all main sections through a main axis in the campus. The main axis is about $1500 \mathrm{~m}$ long and divided by a median, and the vehicle route is around this axis (Figure 3). In the study, $350 \mathrm{~m}$ long section of this $1500 \mathrm{~m}$ long axis was analyzed (Figure 3-4). Based on the on-site analyses and observations using the GIS data, this area was considered suitable for selection for the study are since it collected most of the surface runoff water (Figures 7-8). Because the water flowing from areas 1 and 3 accumulates in the 2nd area due to the reverse slope and inadequate drainage system (region 2 represents the area where the reservoir was planned) (Figures 3-4). Inadequate drainage systems were inadequate for the drainage of water accumulated in the study area due to the reverse slope. The planned reservoir was designed on a strip of the axis since the study area was on the main campus axis. Thus, it was planned to direct the traffic to the second lane while reservoir is constructed on one lane.

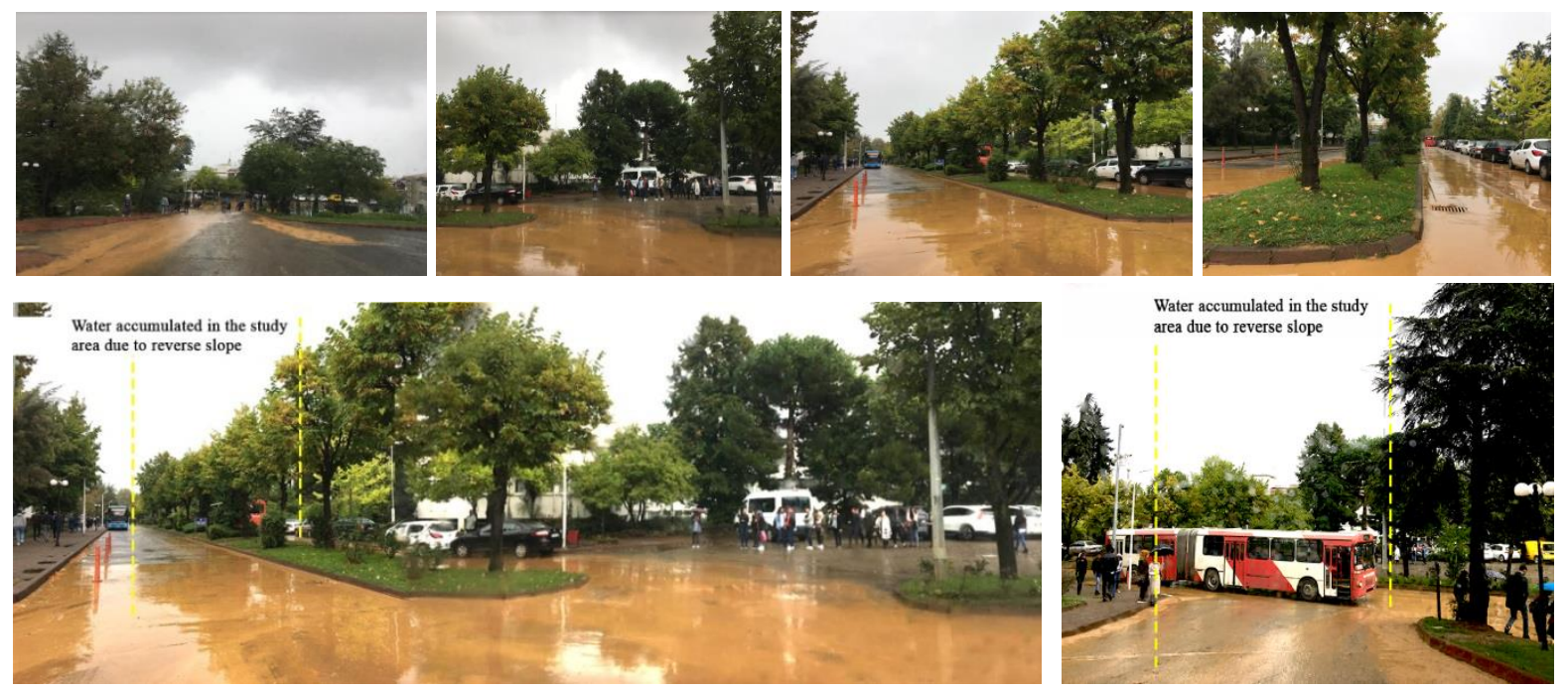

Figure 3. Collection of rainwater in study area due to inverse slope 


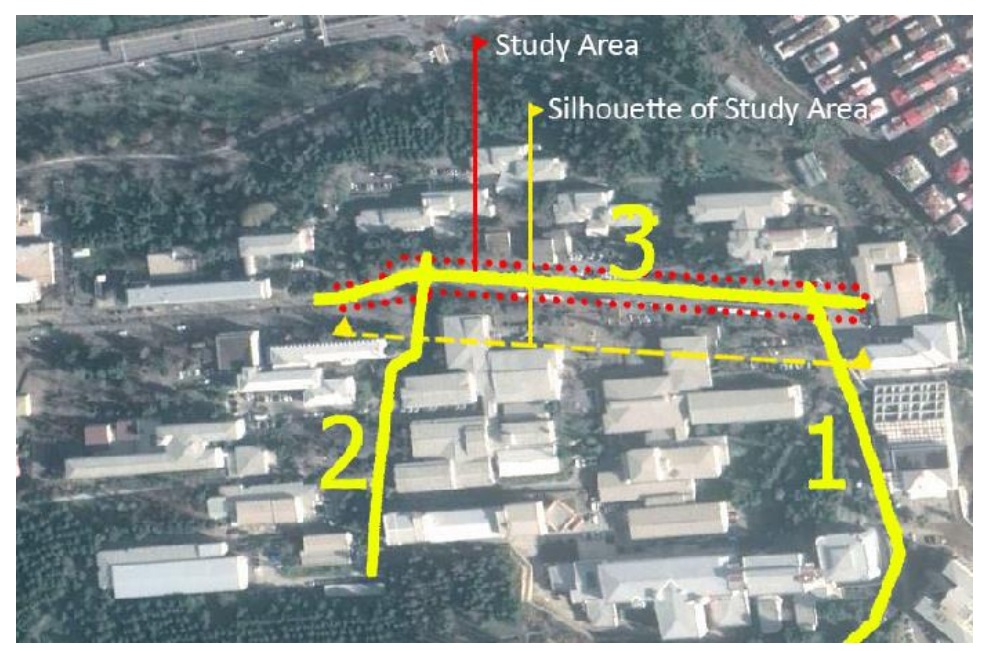

Figure 4. The 3 water distribution regions determined with GIS

\section{RESULTS}

The data on the area selected as the pilot area in the present study (Figure 4) were analyzed based on current topographic findings and the proposed rainwater system approach. The obtained findings are presented under these headings.

\section{Findings on the Topographical Properties of the Study Area (GIS data)}

The digital terrain model and elevation class analysis map for the research area were constructed based on the digital analysis of the study area. Elevation class analysis demonstrated that the highest point in the area at $104 \mathrm{~m}$ altitude. In the region chosen as the pilot area in the study, the altitude varied between 71 and $73 \mathrm{~m}$ and the average slope was $0.57 \%$ (Figure 5). Also, an elevation class map was also developed for the study area to analyze the rainwater direction and accumulation points. Within the campus, there is a significant water flow from $10 \%$ of the selected pilot area at the elevation of $88-105 \mathrm{~m}$ into $25 \%$ of the area with 70-88 $\mathrm{m}$ altitude (Figure 5). Due to this elevation difference in the area, the water flows on the surface towards the pilot area and accumulates in certain parts. The most prominent water collection area is the study area that includes the main axis extending from gate A, which is the main entrance for KTU Kanuni Campus, to the Gate D that leads to Konaklar District. 


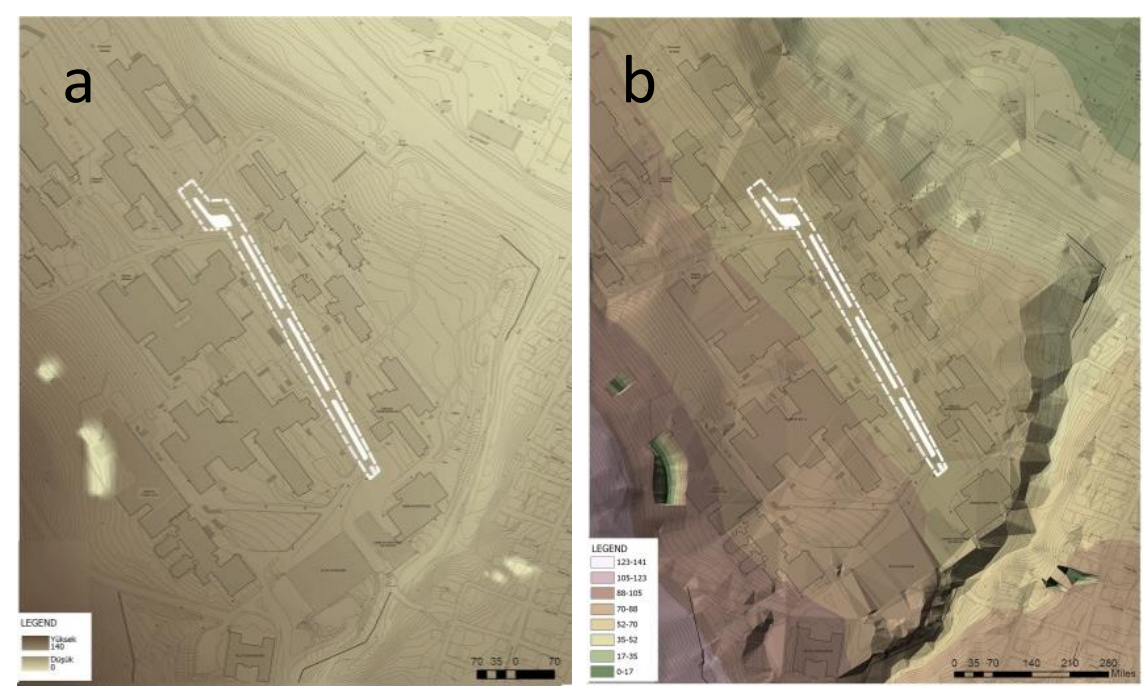

Figure 5. A: Elevation class map B: Digital land model

The study area slope class analysis and exposure analysis maps were constructed based on the digital terrain model (Figure 6). During the development of th slope class map, 6 slope ranges were determined. It was observed that the pilot area had 6-12, 12-20, 20-30 slope ranges based on the above-mentioned slope ranges. This area is bordered by upper zones with a 30+ slope range. The slope difference in the study area, the high number of impermeable surfaces and inadequate infiltration zones cause the majority of water to accumulate in the selected pilot area in rainy days due to the inadequate drainage system. (Figure 3-6A). Another analysis that reflects the other topographic properties of the study is the exposure map. Based on the map findings, it was observed that most of the study area was exposed to northeast. On the other hand, the southwestern area was followed by the south (Figure 6B).
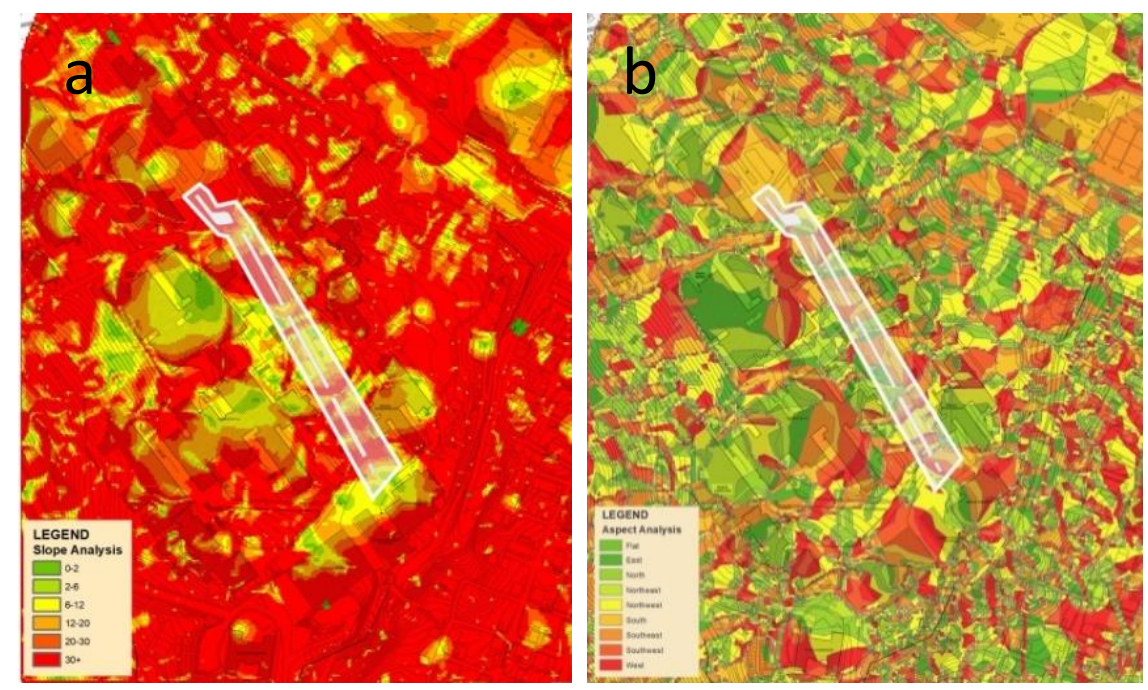

Figure 6. A: Slope analysis B: exposure analysis of the study area 


\section{The Rainwater Collection System Proposed in the Pilot Area}

During the planning of the rain garden, in order to determine how much water would be retained, the surface runoff coefficient should be taken into account. Surface runoff refers to the water from rain, snow or other sources and not retained by soil and plants, did not penetrate to deep soil, did not accumulate in pits, did not vaporize, and flows on the surface. The surface runoff flows on the surface in the direction of the slope without being absorbed by the soil. Surface runoff coefficient is the percentage of the precipitation that flows without evaporation and absorption. Surface runoff coefficient is determined by material permeability, vegetation cover and evaporation rate (PAD, 2017). The runoff coefficient in the formula was used to account for the losses in the collected water (Figure 7).

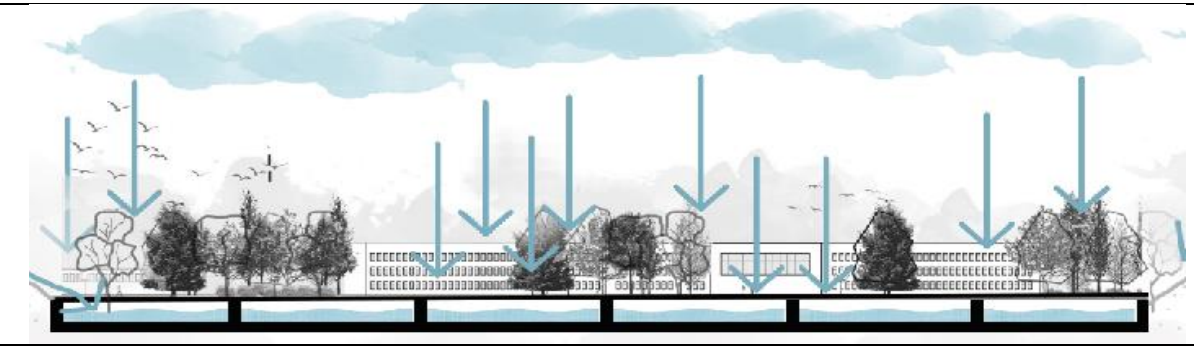

\begin{tabular}{l}
\hline Runoff coefficient: $0,9=$ road; $0,15=$ pasture $(\mathrm{PAD}, 2017)$ \\
\hline Mean annual precipitation: $0.8 \mathrm{~m}^{3}(\mathrm{MGM}, 2018)$ \\
\hline $\begin{array}{l}\text { Water Harvest Formula: Water harvest }=\text { Annual precipitation } \mathrm{x} \text { Surface area } \mathrm{x} \text { Runoff } \\
\text { coefficient (PAD, 2017) }\end{array}$
\end{tabular}

Figure 7. Water collection system proposed in the pilot area

Review of the rainfall data for last 11 years obtained from Trabzon General Directorate of Meteorology demonstrated that the average annual precipitation in Trabzon province Ortahisar District that included the study area was $64.06 \mathrm{~kg} / \mathrm{m}^{2}$. Based on this calculation, the study area annual average rainwater harvest was calculated and included in the study.

Review of the 1 st section of the study area demonstrated that the dominant land surface was impermeable (road) and urban green (meadow-grove). It was calculated in on-site measurements that the surface area of the impermeable area was $3266 \mathrm{~m}^{2}$ and the urban green area was $2265 \mathrm{~m}^{2}$. When the calculation was conducted with precipitation per square meter and corresponding runoff coefficients, the annual runoff in the $1^{\text {st }}$ section was determined as 210.05 $\mathrm{m}^{3}$ (Table 2). 
Table 2. Annual runoff in Section 1

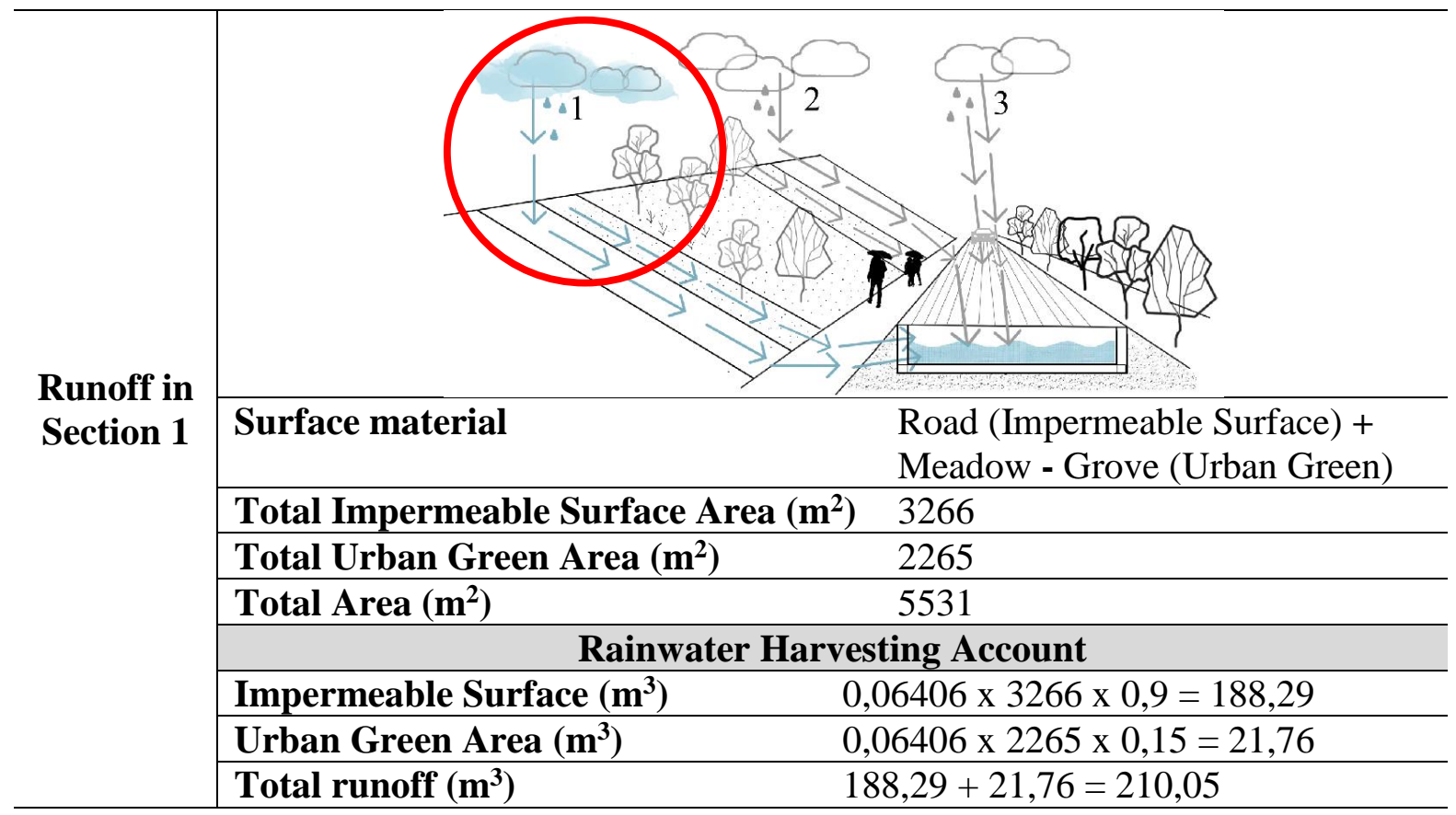

Review of the 2 nd region demonstrated that the dominant land surface was also impermeable (road) and urban green (meadow-grove). It was calculated that the impermeable surface area was $2613 \mathrm{~m}^{2}$ and the urban green area was $2265 \mathrm{~m}^{2}$. The annual runoff in the 2 nd section was calculated as $181.29 \mathrm{~m}^{3}$ (Table 3).

Table 3. Annual runoff in Section 2

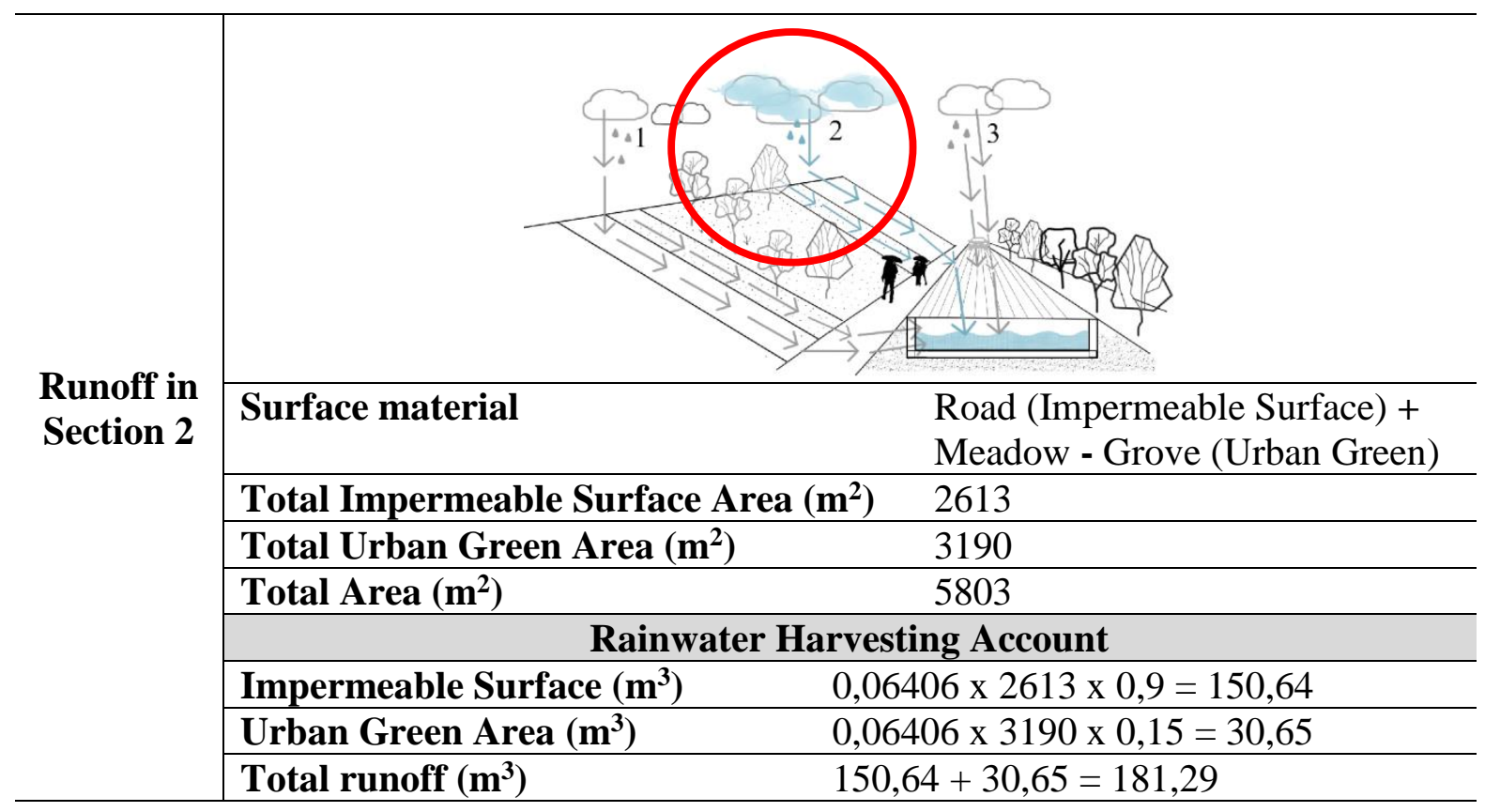


Review of the 3rd section demonstrated that the dominant terrain was impermeable. It was calculated that total impermeable surface area was $2800 \mathrm{~m}^{2}$. The annual runoff in the 3rd section was determined as $161.43 \mathrm{~m}^{3}$ (Table 4).

Table 4. Annual runoff in Section 3

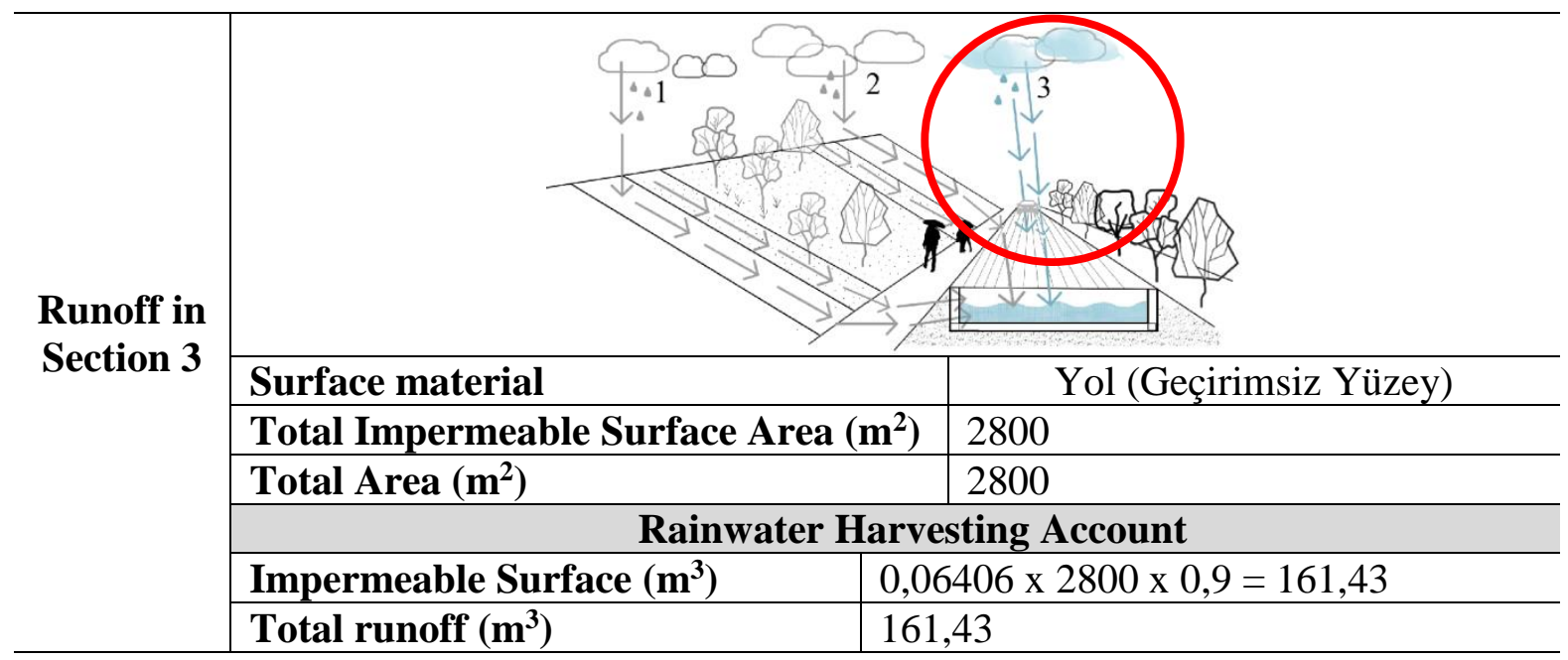

After the surface runoff calculations conducted separately for 3 sections, total surface runoff was calculated for cost analysis (Table 5).

Table 5. The economic value of the collected water

\begin{tabular}{|c|c|c|c|c|}
\hline & Section 1 & Section 2 & Section 3 & \multirow[b]{2}{*}{ Total } \\
\hline & $\frac{21}{11}$ & $11+4$ & $\frac{\infty}{11}$ & \\
\hline Total area $\left(\mathbf{m}^{2}\right)$ & 5531 & 5803 & 2800 & 14.134 \\
\hline $\begin{array}{l}\text { Amount of water } \\
\text { flowing to surface } \\
\left(\mathbf{m}^{3}\right)\end{array}$ & 210.05 & 181.29 & 161.43 & 552.77 \\
\hline $\begin{array}{l}\text { Approximate } \\
\text { economic value of } \\
\text { collected water }(€)\end{array}$ & 411,69 & 355,32 & 316,40 & 1083,41 \\
\hline $1 \mathrm{~m}^{3}$ water $=1,96 €(\mathrm{I}$ & KI, 2018) & & & \\
\hline
\end{tabular}

In the study, a $350 \mathrm{~m}$ section of the road was examined. Based on the GIS data, a rainwater storage system was suggested in order to control the water that moves from higher elevations to lower elevations and to ensure accumulation. The proposed water reservoir was designed to hold $280 \mathrm{~m}^{3}$ water with a height of $1 \mathrm{~m}$, a width of $0.8 \mathrm{~m}$ and a height of $350 \mathrm{~m}$ (Table 1). The required static studies were conducted on the study area and columns were erected in 10-meter 
intervals (Figure 7). The basic principle in implementation of the proposed system approach was the collection and sustainable use of the runoff based on the data obtained with slope maps according to the rainwater collection method. Review of the CIS slope map data demonstrated that the reservoir collected water from 3 zones. The first one is the direct rainfall on the reservoir, the rainfall collected in zone 1, and the rainfall collected in zone 2 (Figure 4-6A). In the scenario selected for the study, rainwater runoff at KTU Kanuni campus surface is collected and transferred to and stored in the reservoir that would be built under the vehicle road using the rainwater transportation systems. The reservoir structure was designed to be built under the vehicle road and included 3 sections: filter zone, pump room and water storage compartment and the water capacity was determined as $183 \mathrm{~m}^{3}$ based on the assumption that irrigation would not be conducted during spring rains (April, May, June, July, August, September) (Figure 7). In the months when no irrigation would be conducted, a connection will be established to the waste water drain with a valve system for evacuation of the water accumulated in the reservoir.

Table 6. Water collection reservoir details

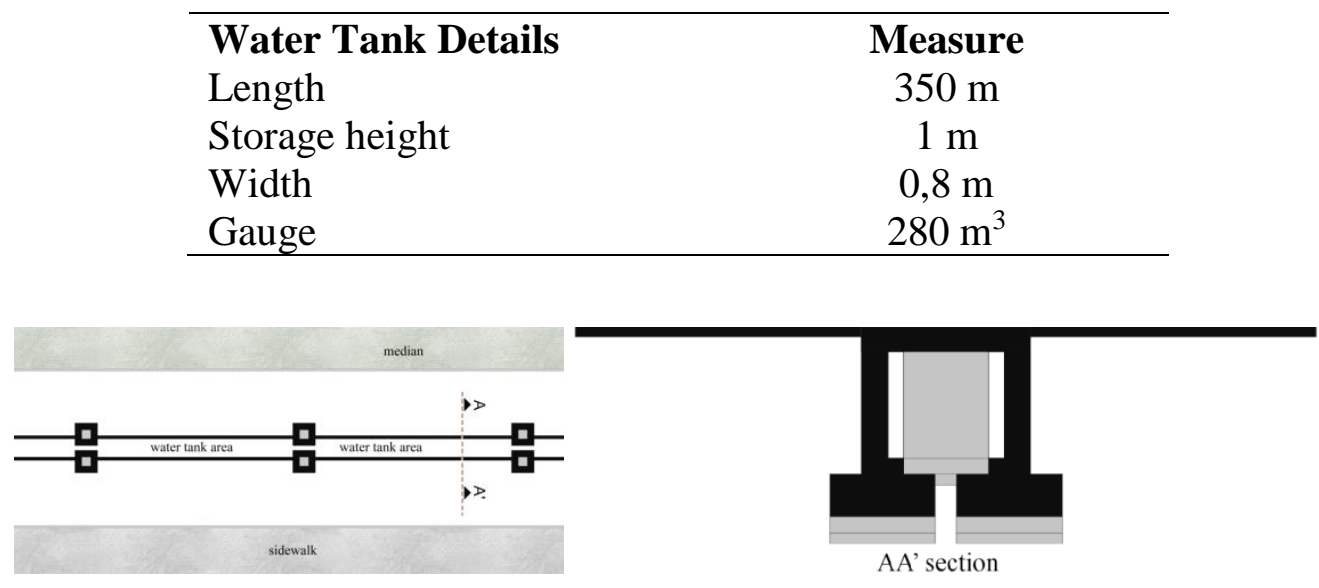

Figure 7. Reservoir detail

The cost of the reservoir planned for rainwater collection was calculated based on Republic of Turkey Environment and Urbanization Ministry 2018 unit price catalog and cost-benefit analysis was conducted (Table 7).

Table 7. Calculation of total rainwater collection reservoir cost 


\begin{tabular}{|c|c|c|c|c|c|}
\hline Pos. No & Type of production & Unit & Amount & $\begin{array}{l}\text { Unit } \\
\text { price } \\
(€)\end{array}$ & Total (€) \\
\hline $14.021 / 1$ & $\begin{array}{l}\text { Cleaning and excavation work at excavation } \\
\text { and landfill area }\end{array}$ & $\mathrm{Yzm}^{2}$ & 63,000 & 5,25 & 330,59 \\
\hline Y.15.006/1A & $\begin{array}{l}\text { Excavation of soft and hard scruff (free } \\
\text { excavation) }\end{array}$ & $\mathrm{m}^{3}$ & 651,000 & 0,79 & 511,35 \\
\hline Y.15.140/02 & $\begin{array}{l}\text { Procurement of gravel and manual pavement, } \\
\text { watering and compaction }\end{array}$ & $\mathrm{m}^{3}$ & 42,200 & 4,29 & 180,92 \\
\hline Y.16.050/13 & $\begin{array}{l}\text { Pouring C } 16 / 20 \text { compressive strength } \\
\text { concrete (produced or procured) (including } \\
\text { transportation) }\end{array}$ & $\mathrm{m}^{3}$ & 10,800 & 26,43 & 285,42 \\
\hline Y.16.050/14 & $\begin{array}{l}\text { Pouring C } 20 / 25 \text { compressive strength } \\
\text { concrete (produced or procured) (including } \\
\text { transportation) }\end{array}$ & $\mathrm{m}^{3}$ & 196,944 & 27,25 & 5367,21 \\
\hline $\begin{array}{l}\text { Y.18.461/00 } \\
2\end{array}$ & $\begin{array}{l}\text { Two-layer waterproofing with } 3 \mathrm{~mm} \text { thick } \\
\text { plastomer-based (bended at }-10 \text { degrees) } \\
\text { polymer bituminous cover with fiberglass } \\
\text { carrier and } 3 \mathrm{~mm} \text { thick plastomer-based ( }-10 \\
\text { cold bended) polymer bituminous cover with } \\
\text { polyester felt carrier }\end{array}$ & $\mathrm{m}^{2}$ & 980,000 & 4,80 & 4705,94 \\
\hline Y.21.001/01 & Production of wooden forms & $\mathrm{m}^{2}$ & $\begin{array}{c}1.481,88 \\
0\end{array}$ & 2,47 & 3663,13 \\
\hline Y.23.015 & $\begin{array}{l}\emptyset 14-\emptyset 28 \mathrm{~mm} \text { ribbed concrete steel bars, } \\
\text { cutting, bending and placement of the bars. }\end{array}$ & Ton & 20,872 & 413,08 & 8621,75 \\
\hline Y.23.176 & $\begin{array}{l}\text { Various iron work production with lama and } \\
\text { profile iron and installation }\end{array}$ & $\mathrm{kg}$ & 684,25 & 1,31 & 897,65 \\
\hline Y.27.585 & $\begin{array}{l}2.5 \mathrm{~cm} \text { thick } 500 \mathrm{~kg} \text { cement-dose screed } \\
\text { production }\end{array}$ & $\mathrm{m}^{2}$ & 981,600 & 3,14 & 3079,24 \\
\hline \multirow[t]{2}{*}{ Y.30.004/A } & $\begin{array}{l}\text { Pavement with } 24 \mathrm{~cm} \text { thick precast } \\
\text { prestressed heavy duty concrete pavement } \\
\text { elements. }\end{array}$ & $\mathrm{m}^{2}$ & 420,000 & 27,37 & 11497,33 \\
\hline & & & & Total (€) & 39140,53 \\
\hline
\end{tabular}

The total water accumulation in the study area was calculated as $6903 \mathrm{~m}^{3}$. In order to calculate the economic value of the collected water, the unit price of water was obtained from the 01.01.2019 statistics as $€ 1.96$, and the economic value was calculated as $1083.41 €$ (Table 5). The approximate cost of the design was calculated as $39.140 .53 €$ based on the discoveryquantity studies (Table 6).

\section{CONCLUSION and RECOMMENDATIONS}

In many parts of the world, it is obvious that sustainable approaches are not preferred especially due to high investment costs. Local governments, civilian authority, and other key players in decision-making mechanisms tend to minimize the expenditures in the period that they are responsible of. Thus, expenditure of the economic inputs on sustainable approaches through infrastructure investments that would not be frequently and easily observed in daily life is not attractive. Therefore, since establishment of the economic performance of sustainable 
approached would mean to speak the same language with "real life," this would be a quite logical approach. In this context, there is a great need to demonstrate the economic performance of the approaches that provide ecological benefits.

The main objective of the present study was to create a movement at this point. Although rainwater collection, accumulation and utilization is a traditional phenomenon, which has been observed in rural areas frequently for quite a long time, it was not observed in urban areas where industrial life is quite dominant.

The price/performance analysis conducted in the present study revealed that the cost of the underground rainwater reservoir that would be constructed under the main artery in the area where most rainwater accumulation was observed at KTU Kanuni Campus was much higher than the economic yield of rainwater collection. However, based on the increasing significance of water and the projection that it would become more significant in the future especially due to urban infiltration problems and global climate change; it could be suggested that the economic value of water would be much higher in the near future. Thus, it is important to note that the investment cost of the reservoir developed in the scenario would be met only once, and that this cost would be below the current costs in future projections, and that the economic and ecological value of the stored water would increase continuously in the future.

Apart from the economic performance, the social responsibility of an educational institution with thousands of students to pass this awareness on to future generations should not be ignored. Passing the awareness on by the generations who would spend years in a campus with the awareness that water is a natural resource that should not be wasted would be beneficial for the acceptance of sustainable approaches worldwide and their inclusion in daily life.

In conclusion, removal of a condition which leads to both water and soil losses, which is neither ecologic nor economic, with a storage method detailed in the present study would constitute a significant ecological, economic and sociological sustainability movement. The potential of this movement to pay itself off in a short time due to its properties should be considered an extremely valuable and undeniable condition.

Water is the source for basic human needs as well as development. Although it is a renewable resource, industrial pollution, population growth, irregular use and pollution of water resources, improper agricultural practices, rapid urbanization and climate conditions that damage water resources and water basins led to water scarcity in several countries. Technological advances, industrialization, rapid consumption of natural resources and population growth have caused climate change and maintenance of life with sustainable resources became impossible. The United Nations declared sustainability mobilization in the 
21 st century. It was suggested that in order to pass on a healthy world to future generations, all countries should participate to create a fair order where the capacity of natural resources are not exceeded, and poverty is eliminated. Sustainable fresh water resources are possible only with the use of precipitation such as rain and snow (PAD, 2017).

\section{REFERENCES}

Akkaş M. (1990) Trabzon İklim Etüdü. Türkiye Cumhuriyeti Başbakanlık Meteoroloji Genel Müdürlüğü Yayınları, Ankara

Akman, Y. (1990). İklim ve Biyoiklim (Biyoiklim Metodları ve Türkiye İklimleri), Palme Yayın Dağıtım, Ankara.

Aravena, J. E., Dussaillant, A. (2009). Storm-water infiltration and focused recharge modeling with finite-volume two-dimensional Richards equation: Application to an experimental rain garden, Journal of Hydraulic Engineering, 135, 1073-1080.

Bayramoğlu E., Demirel Ö. (2011). "Grass plants crop water consumption model in urban parks located in three different climate zones of Turkey", African Journal Of Biotechnology, 18472-18480.

Bayramoğlu E., Demirel Ö., (2016). "Stormwater Management in the Context of Sustainable Drainage Concept in Urban Areas", in: Environmental Sustainability and Landscape Management, Recep Efe, İsa Cürebal, Abdalla Gad, Brigitta Tóth, Eds., St. Klıment Ohrıdskı Unıversity Press Sofia, Sofia, 655-664.

Bilen, Ö. (2015). Suyun Stratejik Önemi. http://ozdenbilen. com/ozdenBilenYayinlari. aspx (arrival at: 13.10.2019).

Davis, A. P.; Shokouhian, M.; Sharma, H.; Minami, C. (2001).Laboratory study of biological retention for urban stormwater management. Water Environ. 73, 5-14.

Davis, A. P.; Shokouhian, M.; Sharma, H.; Minami, C.; Winogradoff, D. (2003). Water quality improvement through bioretention: Lead, copper, and zinc removal. Water Environ. Res. 2003, 75, 73-82.

Davis, A. P., Shokouhian, M.; Sharma, H.; Minami, C. (2006). Water quality improvement through bioretention media: Nitrogen and phosphorus removal. Water Environment. 78, 284-293.

de Miguel, Á., Kallache, M., García-Calvo, E. (2015). The water footprint of agriculture in Duero River Basin. Sustainability, 7(6), 6759-6780.

Demirtaş, M, Sefa, İ.., Irmak, E., Çolak, İ. (2008). Microcontroller Based Dc/Dc Boost Converter For Solar Energy Systems. J. Fac. Eng. Arch. Gazi Univ. 719-728

Dietz, M. E., Clausen, J. C. (2005). A field evaluation of rain garden flow and pollutant treatment. Water, Air, and Soil Pollution, 167 (1-4), 123-138.

Dietz, M.E. Clausen, J.C. (2006). Saturation to improve pollutant retention in a rain garden. Environ. Sci. Technol. 40, 1335-1340.

Dihkan M., Güneroğlu N., Güneroğlu A., Karsli F. (2017). The need for ecosystem-based coastal planning in Trabzon city (TR), International Journal of Environment and Geoinformatics, 4, 192-205. 
Flores, P., Maniquiz-Redillas, M. C., Kim, L. H. (2016). Evaluation on the environmental effects of rain garden treating roof stormwater runoff. Journal of Wetlands Research, 18(1), 10-15.

Flores, P.; Maniquiz-Redillas, M.C.; Geronimo, F.K.F.; Alihan, J.C.P.; Kim, L.-H. (2006B).Transport of nonpoint source pollutants and stormwater runoff in a hybrid rain garden system. J. Wetl. Res. 18, 481-487.

Gultekin, F., Ersoy, A. F., Hatipoglu, E., \& Celep, S. (2012). Trabzon İli Akarsularının Yağışlı Dönem Su Kalitesi Parametrelerinin Belirlenmesi. Ekoloji Dergisi, 21(82).

Gulpinar Sekban, D. (2018). Evaluation of landscape design approaches in post-mining improved landscape (Istanbul Çiftalan-Kisirkaya mine field example), Master's thesis, Turkey

Gulpinar Sekban, D. (2019). Evaluatıon Of Sustainability Potentıal Accordıng To Cittaslow Criterı In Turkey/Trabzon. Fresenius Environmental Bulletin, 25, 1-12.

Guneroğlu N., Acar C., Güneroğlu A., Dihkan M., Karsli F. (2015). Coastal Land Degradation And Character Assessment Of Southern Black Sea Landscape", Ocean \& Coastal Management, 1, 282-289.

Guneroğlu N. (2017). Akarsu Rehabilitasyonunun Peyzaj Kalitesi Üzerindeki Etkileri, Artvin Coruh University Journal of Forestry Faculty, 18, 10-20.

Hong, E.; Seagren, E.A.; Davis, A.P. (2006). Sustainable oil and grease removal from synthetic stormwater runoff using bench-scale bioretention studies. Water Environment, 78, 141155.

Huang, F., Xu, S. (2016). Spatio-temporal variations of rain-use efficiency in the West of Songliao Plain, China. Sustainability, 8(4), 308.

ISKI, 2018. Water Unit Prices, https://www.iski.istanbul/web/tr-TR/musteri-hizmetleri/subirim-fiyatlari

Kim, S., Lee, S. W., Lee, J., An, K. (2018). Exploring the Relationship between Prior Knowledge on Rain Gardens and Supports for Adopting Rain Gardens Using a Structural Equation Model. Sustainability, 10(5), 1500.

Ma, Y., Nall, J., O’Bannon, D. (2018). Assessment of Orifice-Controlled Flow Monitoring Device for Rain Garden Performance. Journal of Sustainable Water in the Built Environment, 4(2).

Maden, T. E. (2013). Havzalar arası su transferinde büyük adım: KKTC İçme Suyu Temin projesi. Ortadoğu Analiz, 5, 50.

MGM, (2018). Meteroloji Genel Müdürlüğü, https://www.mgm.gov.tr/veridegerlendirme/il-veilceler-istatistik.aspx?k=undefined\&m=TRABZON (erişim 27.08.2018).

Muluk, Ç.B., Kurt, B., Turak, A., Türker, A., Çalışkan M.A., Balkız, Ö., Gümrükçü, S., Sarıgül, G., Zeydanlı, U. (2013). Türkiye'de Suyun Durumu ve Su Yönetiminde Yeni Yaklaşımlar: Çevresel Perspektif. İş Dünyası ve Sürdürülebilir Kalkınma Derneği Doğa Koruma Merkezi.

Müftüoğlu, V., Perçin, H. (2015). Sürdürülebilir Kentsel Yağmur Suyu Yönetimi Kapsaminda Yağmur Bahçesi. İnönü Üniversitesi Sanat Ve Tasarım Dergisi, 5(11), 27-37.

PAD, (2017). Peyzaj Araştırmaları Derneği; Yağmur Hasadı Uygulamalarına Giriş Rehberi: İklim Değişikliğine Uyum Kapsamında Bir Çözüm Önerisi, ISBN: 978-605-84032-1-5, PAD Yayın, Ankara

Gülpinar Sekban, D. (2018). Evaluation of landscape design approaches in post-mining improved landscape (Istanbul Çiftalan-Kisirkaya mine field example), Master's thesis, Turkey 
Stander, E. K., Borst, M., O’Connor, T. P., Rowe, A. A. (2010). “TheMeffects of rain garden size on hydrologic performance." World EnvironmentalMand Water Resources Congress 2010, ASCE, Reston, VA, 3018-3027.

Söğüt, N. (2005). ArcGIS 9 Uygulama Dökümanı, İşlem Şirketler Grubu Dökümanları. Ankara.

Şahin, N. İ., Manioğlu, G. (2011). "Binalarda yagmur suyunun kullanılması”. Tesisat Mühendisliği Dergisi, 125, 21-32.

URL-1 http://www.haritamap.com/yer/40148/karadeniz-teknik-unv.html

URL-2 http://www.ktu.edu.tr/ktu-tarihce

URL-3 http://www.trabzon.gov.tr/cografi-ozellikleri

URL-4 http://www.trabzon.gov.tr/cografi-ozellikleri

Zeisl, P., Mair, M., Kastlunger, U., Bach, P. M., Rauch, W., Sitzenfrei, R., Kleidorfer, M. (2018). Conceptual Urban Water Balance Model for Water Policy Testing: An Approach for Large Scale Investigation. Sustainability, 10(3), 716. 